\title{
Losing Real Life: James Baldwin and the Ethics of Trauma
}

\author{
Mikko Tuhkanen Texas A\&M University
}

\begin{abstract}
This essay proposes that we turn to James Baldwin's work to assess the cost of, and think alternatives to, the cultures of traumatization whose proliferation one witnesses in contemporary U.S. academia. Beginning with some recent examples, the essay briefly places these cultures into a genealogy of onto-ethics whose contemporary forms arose with the reconfiguration of diasporic histories in the idioms of psychoanalysis and deconstructive philosophy in 1990s trauma theory. Baldwin speaks to the contemporary moment as he considers the outcome of trauma's perpetuation in an autobiographical scene from "Notes of a Native Son." In this scene-which restages Bigger Thomas's murderous compulsion in Native Son-he warns us against embracing one's traumatization as a mode of negotiating the world. In foregoing what Sarah Schulman has recently called the "duty of repair," such traumatized engagement prevents all search for the kind of "commonness" whose early articulation can be found in Aristotle's query after "the common good" (to koinon agathon). With Baldwin, the present essay suggests the urgency of returning to the question of "the common good": while mindful of past critiques, which have observed in this concept's deployment a sleight-of-hand by which hegemonic positions universalize their interests, we should work to actualize the unfinished potential of Aristotle's idea. Baldwin's work on diasporic modernity provides an indispensable archive for this effort.
\end{abstract}

Keywords: James Baldwin, Mark Lilla, Katherine Franke, trauma theory, Richard Wright 
A fine wound is all I brought into the world; that was my sole endowment.

Franz Kafka, "A Country Doctor"1

Two minor academic scuffles broke out in the disastrous month of November 2016. The internet's queerosphere lit up when word got around about a spectacle that had taken place at Reed College in Oregon on 11 November. Kimberly Peirce, the director of Boys Don't Cry (1999) - a semifictional account of Brandon Teena's life and murder-had been invited to campus to speak to audiences after a screening of her film. According to accounts, a group of transactivist students defaced and removed posters advertising the event, disrupted the Q\&A session by shouting at and over Peirce, and called out the lesbian filmmaker- "a cis white bitch"-for making money and a career on the backs of trans people. The students involved were berated for the historylessness of their perspective, refusal to engage in dialogue, and lack of generosity to their "queer elders."

A week later, a remarkable exchange took place between Mark Lilla and Katherine Franke, both professors at Columbia University. On 18 November, after the election of Donald J. Trump as the President of the United States, Lilla published an op-ed in The New York Times in which he allocated some responsibility for the election results to the divisiveness of what he called "identity liberalism." 3 By this phrase, Lilla meant the fragmentation of the political sphere into various interest groups that, particularly on college campuses, struggle for recognition, greedily participating in what the philosopher Kelly Oliver, too, calls the "era of outrage." To designate the project of shared interests that identity liberalism eschews, Lilla evoked "the common good," a central concept in classical political theory, one whose origin is often traced to Aristotle's use of the phrase (Gr. to koinon agathon) in Politica. ${ }^{5}$ Lilla lamented the loss of commonness through the "narcissistic" insistence with which interest groups plead their own case, in tones of outrage, without any effort at dialogue and compromise.

Anyone marginally fluent in recent academic discourses around politics, hegemony, and social justice will be able to construct a rebuttal to Lilla. In calling for the return of "the common good," he-the response would go-repeats the familiar legerdemain by which a particularity seeks to dominate the political agenda by passing itself off as the universal. Various minority traditions have accomplished considerable work in exposing the methods by which such particularities have pushed their interests under the guise of to koinon agathon. This, indeed, became the gist of Franke's argument in her response to Lilla, published on 21 November in the Los Angeles Review of Books. Franke identified in his contribution an old trick of liberal whitewashing: the hegemonic order constructs a lapsarian narrative where its own voice precedes the dispersal of authentic discourse into the cacophony of narcissistic self-interests. From this perceptive, Lilla's call to relinquish the ever-proliferating discriminations of identity politics is but an effort to reassert the power of an unmarked majoritarian position. For Franke, his misprision is neither innocent nor exceptional: rather, his op-ed evinces that liberalism continues to provide acceptable-New York Times-worthy-guises for 
white-supremacist ideologies. Indeed, she opens her piece by comparing his op-ed with David Duke's celebratory tweet on Trump's victory. That Lilla is a shrewder tricknologist than Duke should not distract us from the fact that they share a project: to make white supremacy respectable, again. ${ }^{6}$

Franke's response shares a frequency with the transactivists at Reed College. This resonance-a certain breathlessness-suggests that those who had shouted down Kimberly Peirce ten days earlier were being good students, merely observing their training, merely honing, by imitating Franke and others, their craft; they were announcing their arrival as appropriately passionate and ambitious agents of the academy. We should here recall that one of the people-a prominent queer scholar-who voiced shock and dismay at the activists' rude heckling had previously, at a public event a decade or so ago, accused an inadequately or erroneously queer colleague of "fascism." Such was an appropriate gesture to mark one's righteous difference from a "queer elder" who had become an early force in queer theory after having made a decades-long contribution to his own disciplinary field. Impassioned commitments were paraded; audiences were entertained; careers were made. But now we must also, in good faith, recognize that the slide from a colleague being called a Nazi to another becoming "a cis white bitch" a decade later is not much of a scandal. No eyebrows should twitch at the easiness with which the shameless ostentation of minority cred in the past returns in the form of the misogynist violence of minor differences that was witnessed at Reed.

There is something more going on at Reed College and Columbia University than the perhaps familiar ritual of elder cannibalization. These events constitute examples of what we can call the culture of "trauma pride." By trauma pride, I mean a set of firmly-but, as I will note, relatively recently-established onto-ethical assumptions concerning the subject's orientation in a world of radical differences. Because differences are "radical" - constitutive, "of the root"-appeals to that which is "shared" or "common" (koinon) are to be considered traps of ideological misrecognition. Hence, in this schema, it is deemed politically and ethically imperative to persist in one's trauma, for it designates a singularity that must not be dissipated by such ideologies as the liberal ethos of commonness. I will suggest that James Baldwin's work allows us to assess the costs of, and think alternatives to, these contemporary cultures of traumatization, which have become particularly pervasive in U.S. academia.

In many fields of the so-called soft sciences, graduate school awards one a new, compelling idiom with which to describe the world and one's place in it. The conversion experience of the graduate school-or one's undergraduate years at an elite liberal arts institution-functions with the force of a biopolitical productivity, and, like other modes of biopolitics, it has a specific, traceable genealogy. This genealogy hinges on "trauma theory," a field that came into its own in U.S. academia in the 1990s as it radicalized previous formulations of traumatism. Its representatives now argued that trauma must be understood as the subject's constitutive condition. Psychoanalytically oriented thinkers took their cues from the likes of Freud and Jean Laplanche, abetted by Jacques Derrida's reading of Nicholas Abraham and 
Maria Torok. ${ }^{7}$ In developing deconstructive ethics, Derrida convinced us that what Freud calls "mourning" is never to be over and done with; that it is imperative for us not to be successful in the work of "decathecting" the lost object. Annihilating the object a second time, successful mourning is an ethical betrayal. In order to respect the singularity of our others, we must refuse to bring the work of mourning to the kind of closure that Freud imagined as the therapeutic goal; we must accept the fact that "mourning is interminable."

Not coincidentally, trauma theory developed simultaneously with the academic articulation of contemporary Holocaust and Diaspora Studies. Scholars thinking through the ethical challenge of the Holocaust insisted on the ineffable otherness of this quintessential twentieth-century experience. Echoing Derrida's reading of Freud, trauma theorists argued that the wound of mid-century European terror is never to be fully remembered, much less healed; that, constitutively, its trauma cannot be gotten over, not without dismissing the unthinkable horror of bureaucraticized genocide. At the same time, scholars working in African Diaspora Studies began to suggest that we read the African American as a perpetually traumatized subject. They followed a number of black American writers who have, at least since the Reconstruction, suggested the traumatization-both spectacular and insidious - of black life in the United States. From Pauline Hopkins to Toni Morrison, these writers point out that, if modern subjectivity is marked by alienation, expulsion, and (wage) slavery, it is the African diasporic subject, rather than the European industrial laborer, who is the earliest exemplar of modernity's disaffection.

The displays of trauma pride at Reed College and Columbia University are informed by these important histories. The arguments made in Holocaust and Diaspora Studies, aided by poststructuralist configurations of modernity, have developed into claims about the dignity and unassailability of trauma. The demands for trigger warnings and safe spaces are ways to flexibly encounter the irreducibly different ways people experience the world. Yet their genealogies lead to arguments about constitutive injury. As the unprocessed-importantly, unprocessable-cut that births the subject, trauma has become a site where people insist on their unnamable individuality. As the psychoanalyst Adam Phillips writes, we have come to understand "the traumatized self as the normal, modern self, so to speak." But as is always the case, such modes of conceptualization become anachronisticbecome ethical liabilities-almost as soon as they are instituted: call it the chronic out-of-jointness of human existence.

In the literature with which I have spent most of my scholarly career, the repeated trope of awakening marks an ethical call for us to address the stubborn failure, but also the persistent dream, of a shared world. We can designate this realm with Heraclitus's term koinos kosmos, the common world of wakefulness where shared experience-and, hence, the prospect of to koinon agathon-still remains a possibility, despite its frequent rhetorical hijacking by hegemonic interests. The famous alarm clock that opens Richard Wright's Native Son (1940) has been read as an urgent appeal for people in the mid-twentieth-century United States to wake 
up to the realities of life in diasporic modernity. This is the nightmare of history that, as Wright and other African-American writers have noted, has been studiously disavowed by such varied means as the hegemonic culture industry, the Dunning school of history, and the philosophy of pragmatism. Writing his debut novel in the late 1930s, Wright takes his place in the long line of America's black oneiropolists by arguing that what Heraclitus would call the idios kosmos-the idiosyncratic world of one's dreams-of American life has left the novel's protagonist, Bigger Thomas, susceptible to the lure of fascism, fascinated by newspaper stories of Hitler's and Mussolini's exploits. ${ }^{10}$ The gathering catastrophe of midcentury Europe invests Wright's project with an urgency: we must wake up from the dream lest the fascist social bond be the only remaining lifeline to save us from our unshareable suicides. In ways that are infrequently noted, Wright here anticipates Hannah Arendt's later analysis of the "solitary" modern subject's vulnerability to fascist demagoguery. ${ }^{11}$

In a scene from the early essay "Notes of a Native Son" (1955), James Baldwin revises the nightmare that leads to Bigger's accidental murder of Mary Dalton, the well-intentioned white girl who doesn't quite understand the provocation that her reckless assumption of anything shared, any morsel of koinon, with the black man constitutes in a world split by the color line. The autobiographical scene of Baldwin's young adulthood-which Karen Thorsen perceptively illustrates in her 1989 documentary James Baldwin: The Price of the Ticket-describes his first encounter with Southern-style antiblack racism as he is working on a construction site in New Jersey. ${ }^{12}$ After experiencing days of racist taunting, the young Baldwin is overtaken by a "rage in his blood": ${ }^{13}$ his world suddenly distorted as if "by an optical illusion, or a nightmare," ${ }^{14}$ he marches into a restaurant that he knows to practice segregation, "with a determination to be served or to die." This phrase, which Baldwin uses in an interview included in Thorsen's documentary, immediately recalls Patrick Henry's and Frederick Douglass's refusals to continue accepting the social death that has constituted their enslavement. Henry and Douglass are figures in a genealogy of heroism, of overcoming insurmountable oppression, whose most recent theorists include Orlando Patterson (Slavery and Social Death), Judith Butler (The Psychic Life of Power), and Abdul JanMohamed (The Death-BoundSubject). ${ }^{15}$ For these thinkers, an encounter with the hostile world that, as Frantz Fanon writes in The Wretched of the Earth (1961), has "fabricated" the subject requires the self's unraveling, social death's literalization in a suicidal wager. ${ }^{16}$

But Baldwin's point is remarkably different from Henry's or Douglass's (or Patterson's and Butler's and JanMohamed's). He describes his younger self in the grip of something like a psychosis, entering the idios kosmos of "a nightmare" that each lives in his solitude. It is in this nightmare that the white waitress who meets him at the door comes to him as his mortal enemy. She tells the black man that Negroes are not served in the establishment. The woman's demeanor is "apolog[etic]," which only serves to deepen Baldwin's "cold" rage. ${ }^{17}$ Because he can't get closer to the woman, he grabs a glass of water and throws it at her. She dodges, and the glass 
shatters the mirror behind the bar. The sound breaks the spell, the "nightmare," that had enveloped Baldwin, and he awakens:

with that sound, my frozen blood abruptly thawed, I returned from wherever I had been, I saw, for the first time, the restaurant, the people with their mouths open, already, as it seemed to me, rising as one man, and I realized what I had done, and where I was, and I was frightened. ${ }^{18}$

Afterwards, as he replays the events, the scene returns to him in the form of the repetition compulsion that frequently attends traumas' aftermaths. The traumatizing terror of the event consists not primarily in his realization of how close he had come to dying. Rather, the epiphany concerns the fact that he "been ready to commit murder": "I saw nothing very clearly but I did see this: that my life, my real life, was in danger, and not from anything other people might do but from the hatred I carried in my own heart." ${ }^{19}$

Even though autobiographical, the scene should be read as a retelling of Bigger's deadly encounter with Mary Dalton and her blind mother. In identifying the woman as his mortal enemy, the young Baldwin is about to commit a tragic error: the hamartia of killing the messenger, the "frightened" waitress who speaks to him with "a note of apology in her voice," as if "repeat[ing lines] she ha[s] learned ... somewhere." ${ }^{20}$ This is how, Baldwin suggests, the tragedy of American race relations perpetuates itself: blinded by rage, unable to take his eyes off the contingent embodiment of an impersonal history, the young man is on the cusp of joining the unwitting performers of diasporic modernity's tragic scripts. As Baldwin repeatedly tells us, his adoptive father unfailingly excels in such misdirected, rageful performances; Bigger Thomas - another paternal, or perhaps fraternal, figure to be disowned-embodies the paradigmatic victim/perpetrator of the hopeless dialectic that is about to engulf the narrator of "Notes of a Native Son." The server is a Mary Dalton, a well-meaning but clueless messenger from beyond enemy lines, unable to fully understand the role she plays for the black man. She is also, importantly, his doppelgänger, a reverse image, projected onto the mirror that accidentally, and mercifully, breaks as he reaches out to annihilate his double.

The epiphany that closes the autobiographical scene anticipates many of Baldwin's later observations about the tight grip of diasporic modernity's death dialectic, particularly as it squeezes the life out of the populations of the United States. Baldwin makes a point of noting that his awakening in the restaurant was to the jeopardy not primarily of his physical survival-although it is also thatbut of what he calls his "real life." Real life will have been lost whether the young man survives the confrontation or not. Such real-ness names the possibility of a life beyond the scripts that position him and the waitress as doppelgängers and enemies, uncanny twins: a world of potential of which Bigger gets an inkling amid the confusion of his sudden awakening on the morning following the murder that the young Baldwin narrowly avoids repeating. ${ }^{21}$ Real life is irrevocably lost in the 
paranoid politics of otherness that allows Bigger the delusion of agency while, simultaneously, sealing his doom in the freezing cityscape of Chicago, an emblem of the modern world that, as Wright puts it in his early manifesto on black letters, "has grown huge and cold."22 While Bigger, awakened for a split second, finds himself in a world of undetermined potential, his tragedy-the perpetual loss of his real life-is inescapable: the snow is already falling as he opens his eyes on the morning after the murder. This frozen world infects the young Baldwin, too, with a "cold" rage. In writing that the mirror's accidental shattering "thaw[s]" his blood, Baldwin picks up the term from Bigger's lawyer, Boris Max, as he issues an urgent call for the "thawing out" of the diasporic nation's "icebound impulses."'23

Unlike the celebrants of trauma pride in contemporary academia, Baldwin insists that allowing trauma to become the mode of negotiating the frictional world constitutes a devastating error. Kleinians have a diagnostic term for the pathology: they call it the "paranoid-schizoid position," the production of delusions that results from a person's inflexible terror of difference. ${ }^{24}$ The "paranoid imperative," whose hegemony Eve Kosofsky Sedgwick two decades ago discerned in contemporary scholarship, similarly describes the attitude that horrified Baldwin in Wright's protagonist: the alertness that ultimately exhausts Bigger coincides with the vigilance of Sedgwick's paranoid reader, who braces herself against the hostile world's ongoing, and often deviously disguised, assaults. ${ }^{25}$ Given our context, Fanon provides a particularly useful analysis of the onto-ethical stance of traumatism. In Black Skin, White Masks (1952), he borrows the term "Manichean delirium" from early twentieth-century clinical psychiatry, where it designates the psychotic patient's efforts to parry with a world organized according to rigid dualisms. ${ }^{26} \mathrm{He}$ continues the analysis with his description, in The Wretched of the Earth, of the way in which the "compartmentalized, Manichean and petrified" world of the colonized society catches both the colonizer and the colonized in the kind of specular relationship that Baldwin allegorizes in "Notes of a Native Son."27 "The violence of the colonial regime and the counterviolence of the colonized balance each other and respond to each other in an extraordinary reciprocal homogeneity," Fanon writes; "the Manichaeanism of the colonist produces a Manichaeanism of the colonized." ${ }^{28} \mathrm{Sim}-$ ilarly, the consequences of colonial terror-the "permanent state of tension" and "constant muscular tonus" of the colonized-precipitate countermeasures where the oppressed use their paranoid preparedness to shift from their position of the quarry to that of the hunter. ${ }^{29}$ Constituting something like an embodied version of what Michel Foucault calls "'reverse' discourse," such responses often come with catastrophic consequences. ${ }^{30}$ It is the black man's muscle tension, caused by the overdetermination of his being in modernity, that kills the white daughter in Native Son. Manicheanism similarly produces the dreamlike frenzy ("an optical illusion, or a nightmare") under which the young Baldwin nearly murders his doppelgänger in the New Jersey restaurant.

Franke ridicules Lilla for his cushy position, imagining him sipping his espresso in Paris while pontificating about minority politics in the United States. Yet in 
the same cafés we may have also found Baldwin, debating other diasporic writers, agonizing over his absence from the gathering storm of the civil rights fight in his native country, and quarrelling with Richard Wright. Baldwin left the United States for Europe in 1948. Thorsen's documentary, James Baldwin: The Price of the Ticket, suggests a direct causation between his experience in New Jersey and the escape to Paris. Undoubtedly, Lilla gets to enjoy the European capital with better funding than the struggling young writer; he has most likely never seen the inside of a Paris jail cell like Baldwin, who found himself arrested for allegedly stealing linen from a hotel. ${ }^{31}$ What Baldwin tells us about his life-saving self-removal from the hall of mirrors may nevertheless be important for the contemporary moment.

The move to Paris, he writes, "taught me things I did not know (how to take a deep breath, for example)."32 Breathlessness brings nothing but what Baldwin, in a later interview, calls "real death," in a phrase that echoes, italics and all, the one he uses in "Notes of a Native Son." In a 1970 interview in Essence, he recalls his escape to France:

I arrived [in Paris] with $\$ 40$, scared to death, not knowing what I was going to do, but knowing that whatever was going to happen here would not be worse than what was certainly going to happen in America. Here I was in danger of death; but in America it was not a danger; it was certainty. Not just physical death, I mean real death. ${ }^{33}$

"Real death" threatens to abolish "real life"; it is this annihilation that Baldwin flees.

It is very hard, Baldwin suggests, not to trump craziness with one's own tragic insanity. Despite his appreciation of the affirmative narratives offered by the Nation of Islam, he considered Elijah Muhammad's ideology but a continuation of the oneiric delusions of white supremacy: "The dream, the sentiment is old, only the color is new," he observed of the Nation of Islam's program in The Fire Next Time. ${ }^{34}$ It is extremely difficult, in the polarized world of traumatization, to prevent the mirror from luring one into the most tortuous of doppelgänger poses. Yet the most exigent thing to do, always, is to shatter Narcissus's instrument, for engagement in the politics of Manichean delirium comes with an incalculable price: the annihilation of real life, one's recruitment into the trauma squads, and the loss of all breathing space.

If exile lets Baldwin "take a deep breath" and escape "real death," what follows is nothing like the steadiness of restful respiration. The French term for breathing, souffler - as in, for example, reprendre son souffle-would perhaps have evoked for him souffrance, suffering. In suffering, one is en souffrance, suspended on the journey. Such suffering necessitates the "continual pausing for breath" that, as Walter Benjamin - another tragically diasporic subject-tells us, is necessary for thinking. ${ }^{35}$ Most explicitly perhaps in the short story "Sonny's Blues" (1957), Baldwin insisted on suffering - and, we can add, breathing-as the common ground of human experience. ${ }^{36}$ The screaming by which one declares one's singular wound, on the contrary, leaves a trauma queen breathless, stalls the journey. 
As woundedness, traumatization may precipitate an openness to the world; yet the cut is often cultivated into scar tissue that not only ostentates one's pedigree of pain, but also numbs and paralyzes the site of injury. As Edward Said observes, "trauma can lead not to the openness of diasporic identities, but to dogma and delusion instead." Too often

trauma, far from generating freedom, openness to others as well as to the divided and unresolved fragments of a self, leads to a very different kind of fragmentation-one which... causes identities to batten down, to go ... toward dogma, the dangers of coercive and coercing forms of faith. ${ }^{37}$

Sarah Schulman has addressed this tendency in Conflict Is Not Abuse: Overstating Harm, Community Responsibility, and the Duty of Repair (2016), her remarkably nuanced meditation on the Manichean delirium embraced, as an ethical imperative, in various scenes of conflict, by the fragile narcissists on both sides of the looking glass. She analyzes the ways in which "Supremacy" and "Trauma" constitute mutually perpetuating, dialectical responses to each other. "Perhaps because Supremacy in some produces Trauma in others, they can become mirror images," she writes. ${ }^{38}$ Like Baldwin, she calls for the breaking of "the Supremacy/Trauma mirror," which has frozen both the victim and the perpetrator in postures of fascinated terror. ${ }^{39}$

As evinced by The Once and Future Liberal: After Identity Politics (2017), the book he wrote on the heels of his New York Times op-ed, Lilla is not-of course not-unfamiliar with the history of political contestation in which "the common good" has been deemed by some an ideological chimera meant to prolong the disempowerment of the marginal. ${ }^{40}$ The history he provides in his polemic may be peculiarly slanted, contain omissions, or be colored by the author's politicoethical convictions. Even then, the differences between him and Franke amount to an intellectual-political disagreement or conflict, and conflict, as Schulman tells us, is not abuse-not the life-threatening infringement that trauma culture's paranoid imperative has rendered us ever ready to call out and repulse. Identifying Lilla with David Duke, and collapsing the long tradition of liberalism with white supremacy, Franke's rejoinder executes the swift "escalation into hyperbole" that Schulman identifies as typical to trauma discourse. ${ }^{41}$ The breathless response closes any space in which one could regard Lilla's intervention as a call for a rethinking of to koinon agathon and consider the possibility that the return he solicits is not to an unchanged past. We may be tempted to respond to such efforts as the young Baldwin reacts to the waitress, infuriated into blindness by what we take to be an all-too-familiar insult. And for good reasons: the rethinking of koinon that I discern in Lilla's op-ed and book is risky, for it necessarily overlaps with the crassest of power's ruses. We hear its echoes in, for example, the predictable appeal that Donald Trump's speech writers had him ventriloquize after the baseball shootings in Virginia in June 2017: "we are strongest when we are unified and when we work together for the common good." ${ }^{2}$ Yet if we delay our response, refuse to 
recognize the Manichean other in the mirror, we may also observe Wright's suggestion, closely resonating with Hannah Arendt's, that it is diasporic modernity's eradication of "common and good," the loss of "common ideals," that renders a population vulnerable to the promise of the common bond of fascism. ${ }^{43}$ This, too, should sound familiar, for Wright's early analysis of fascism's rise anticipates some of the explanations offered for the results of the 2016 presidential elections.

Even if, all evidence to the contrary, Lilla did advocate a return to the most regressive politics of unmarkedness-as-koinon, we may not want to miss the opportunity to consider his gesture apart from its nefarious intention, that is, to reopen the question of the common good after-and mindful of the lessons of the politics of traumatization. The call for new experimentations with koinon is also, among other things, a plea for civility. Like "the common good," the hegemonic mode of this concept has been ably deconstructed by scholars, showing how the protocols of "respectability" and "reason" muffle critiques that come off as too combative, pugnacious, and militant. ${ }^{44}$ Yet given the historical context in which this critique occurs-the context I have tried to map here-it itself quickly becomes a lazy refusal at self-risking. What then remains is the embrace of trauma pride such as we witness at Columbia University and Reed College. A critique of civil discourse can take place in civil discourse, as much as the critique of the history of Reason can be spoken in rational language. Despite their constitutive contamination in diasporic modernity, only reason and good will can save us now. Break the mirror, leave home, act civilly, self-reflect. Breathe. Paris will be great.

\section{Notes}

1 Franz Kafka, "A Country Doctor," in The Complete Stories, ed. Nahum N. Glatzer (New York, Schocken, 1983), p. 225.

2 Jack Halberstam, "Hiding the Tears in My Eyes-Boys Don't Cry-A Legacy," Bully Bloggers, 7 December 2016, https://bullybloggers.wordpress.com/2016/12/07/hiding-thetears-in-my-eyes-boys-dont-cry-a-legacy-by-jack-halberstam/ (accessed 3 March 2018). See also some of the comments on the online piece.

3 Mark Lilla, "The End of Identity Liberalism," New York Times, 18 November 2016, www.nytimes.com/2016/11/20/opinion/sunday/the-end-of-identity-liberalism.html? $\mathrm{r}=0$ (accessed 13 June 2018).

4 Kelly Oliver, "If This Is Feminism...," Philosophical Salon, 8 May 2017, http:// thephilosop-hicalsalon.com/if-this-is-feminism-its-been-hijacked-by-the-thoughtpolice/ (accessed 3 March 2018).

5 Aristotle, Politica, trans. Benjamin Jowett, in The Basic Works of Aristotle, ed. Richard McKeon (New York, Modern Library, 2001), III.6-7.

6 Katherine Franke, "Making White Supremacy Respectable. Again," Los Angeles Review of Books, 21 November 2016, http://blog.lareviewofbooks.org/essays/making-whitesupremacy-respectable/ (accessed 13 June 2018).

7 The most important of the trauma theorists who embraced poststructuralist rereadings of psychoanalysis, including Derrida's, were Shoshana Felman and Dori Laub (Testimony: Crises of Witnessing in Literature, Psychoanalysis, and History [New York, 
Routledge, 1991]) and Cathy Caruth (Unclaimed Experience: Trauma, Narrative, and History [Baltimore, MD, Johns Hopkins University Press, 1996]; see also Caruth's edited collection Trauma: Explorations in Memory [Baltimore, MD, Johns Hopkins University Press, 1995]). The term "trauma theory" is originally Caruth's. See Unclaimed Experience, p. 72.

8 Jacques Derrida, The Work of Mourning, ed. Pascale-Anne Brault and Michael Naas (Chicago, University of Chicago Press, 2001), p. 143. For a recent consideration of Derrida's ethics of mourning, see Geoffrey Bennington, Half Not No End: Militantly Melancholic Essays in Memory of Jacques Derrida (Edinburgh, Edinburgh University Press, 2010).

9 Adam Phillips, Becoming Freud: The Making of a Psychoanalyst (New Haven, CT, Yale University Press, 2014), p. 105.

10 Richard Wright, Native Son (New York, Perennial, 1993), p. 115.

11 See Hannah Arendt, The Human Condition, 2nd ed. (Chicago, University of Chicago Press, 1998); and The Origins of Totalitarianism (Cleveland, OH, Meridian, 1969). For discussion of this aspect of Arendt's postwar political theory, see Jennifer Gaffney, "Another Origin of Totalitarianism," Journal of the British Society for Phenomenology, 47:1 (2016), pp. 1-17.

12 Karen Thorsen (dir.), James Baldwin: The Price of the Ticket (Maysles Films and PBS/American Masters, 1989).

13 James Baldwin, "Notes of a Native Son," in Collected Essays, ed. Toni Morrison (New York, Library of America, 1998), p. 70.

14 Ibid.

15 Orlando Patterson, Slavery and Social Death: A Comparative Study (Cambridge, MA, Harvard University Press, 1982); Judith Butler, The Psychic Life of Power: Theories in Subjection (Stanford, CA, Stanford University Press, 1997); Abdul R. JanMohamed, The Death-Bound-Subject: Richard Wright's Archaeology of Death (Durham, N.C., Duke University Press, 2005).

16 Frantz Fanon, The Wretched of the Earth, trans. Richard Philcox (New York, Grove Press, 2004), p. 2.

17 Baldwin, "Notes of a Native Son," p. 71.

18 Ibid., pp. 71-2.

19 Ibid., p. 72.

20 Ibid., p. 71.

21 Wright, Native Son, p. 97.

22 Richard Wright, "Blueprint for Negro Writing," in Richard Wright Reader, ed. Ellen Wright and Michel Fabre (New York, Da Capo Press, 1997), p. 49.

23 Wright, Native Son, p. 383.

24 On Klein's relevance to Baldwin's work, see David W. McIvor, "The Struggle for Integration: James Baldwin and Melanie Klein in the Context of Black Lives Matter," James Baldwin Review, 2 (2016), pp. 75-96.

25 Eve Kosofsky Sedgwick, "Paranoid Reading and Reparative Reading; or, You're So Paranoid, You Probably Think This Introduction Is about You," in Eve Kosofsky Sedgwick (ed.), Novel Gazing: Queer Readings in Fiction (Durham, N.C., Duke University Press, 1997), pp. 1-37.

26 Frantz Fanon, Black Skin, White Masks, trans. Richard Philcox (New York, Grove Press, 2008), p. 160.

27 Fanon, The Wretched of the Earth, p. 15. 
28 Ibid., pp. 46, 50.

29 Ibid., pp. 16-17. While I have used Fanon's account of colonial relations to illuminate the anecdote in "Notes of a Native Son," we should observe that, for Fanon, colonization's Manicheanism constitutes but a stage in a complicated dialectical journey, one that Baldwin refuses to embark upon. Because of this, all further comparisons between the two thinkers should heed the profound incompatibility between their philosophies: whereas Fanon tracks the emergence of subaltern consciousness from the "zone of nonbeing" in the system of colonial whiteness, Baldwin insists that conceptualizing identities dialectically is a mistake. For an insightful account of Fanonian dialectics, see George Ciccariello-Maher, Decolonizing Dialectics (Durham, N.C., Duke University Press, 2017), chapters 2 and 3.

30 Michel Foucault, The History of Sexuality, Volume 1: An Introduction, trans. Robert Hurley (New York, Vintage, 1990), p. 101.

31 James Baldwin, "Equal in Paris," in Morrison (ed.), Collected Essays, pp. 101-16.

32 James Baldwin, "Notes for The Amen Corner," in The Amen Corner (London, Penguin, 1991), p. 10.

33 James Baldwin, "Conversation: Ida Lewis and James Baldwin," Essence, 16 (October 1970), p. 24, emphasis in original. The dialogue is reprinted in Conversations with James Baldwin, ed. Fred L. Standley and Louis H. Pratt (Jackson, MS, University Press of Mississippi, 1989), pp. 83-92.

34 James Baldwin, The Fire Next Time, in Morrison (ed.), Collected Essays, p. 319.

35 Walter Benjamin, The Origin of German Tragic Drama, trans. John Osborne (London, Verso, 2003), p. 28.

36 James Baldwin, "Sonny's Blues," in Early Novels and Stories, ed. Toni Morrison (New York, Library of America, 1998), pp. 831-64.

37 Edward W. Said, Freud and the Non-European (London, Verso, 2004), pp. 69, 75-6.

38 Sarah Schulman, Conflict Is Not Abuse: Overstating Harm, Community Responsibility, and the Duty of Repair (Vancouver, Arsenal Pulp Press, 2016), p. 145.

39 Ibid., p. 157.

40 Mark Lilla, The Once and Future Liberal: After Identity Politics (New York, Harper, 2017).

41 The expedient phrase "escalation into hyperbole" is Denise Balkissoon's; see her discussion of Schulman in "Women Don't Have to Agree, but We Do Need to Fight Fair," Globe and Mail, 18 January 2018, www.theglobeandmail.com/opinion/women-dont-have-toagree-but-we-do-need-to-fight-fair/article37660611/ (accessed 3 March 2018).

42 Quoted in Emmanuel Ocbazghi, "President Responds to a Shooting at Congressional Baseball Practice at Virginia," Business Insider, 14 June 2017, www.businessinsider.com/ president-trump-responds-shooting-congressional-baseball-practice-virginia-policegun-steve-scalise-2017-6 (accessed 15 June 2017).

43 Wright, Native Son, pp. 362, 387.

44 See Tav Nyongo, "Civility Disobedience," Bully Bloggers, 18 August 2014, https://bully bloggers.wordpress.com/2014/08/18/civility-disobedience/ (accessed 11 January 2017).

\section{Works Cited}

Arendt, Hannah, The Human Condition (2nd ed. 1958) (Chicago, University of Chicago Press, 1998). The Origins of Totalitarianism (1951) (Cleveland, OH, Meridian, 1969). 
Aristotle, Politica, trans. Benjamin Jowett, in The Basic Works of Aristotle, ed. Richard McKeon (1941) (New York, Modern Library, 2001), pp. 1113-316.

Baldwin, James, Collected Essays, ed. Toni Morrison (New York, Library of America, 1998). "Conversation: Ida Lewis and James Baldwin," Essence, 16 (1970), pp. 22-7. Conversations with James Baldwin, ed. Fred L. Standley and Louis H. Pratt (Jackson, MS, University Press of Mississippi, 1989).

"Equal in Paris" (1955), in Collected Essays, ed. Toni Morrison (New York, Library of America, 1998), pp. 101-16.

The Fire Next Time (1963), in Collected Essays, ed. Toni Morrison (New York, Library of America, 1998), pp. 287-347.

"Notes for The Amen Corner," in The Amen Corner (1969) (London, Penguin, 1991), pp. 8-14.

"Notes of a Native Son" (1955), in Collected Essays, ed. Toni Morrison (New York, Library of America, 1998), pp. 63-84.

"Sonny's Blues" (1957), in Early Novels and Stories, ed. Toni Morrison (New York, Library of America, 1998), pp. 831-64.

Balkissoon, Denise, "Women Don't Have to Agree, but We Do Need to Fight Fair," Globe and Mail, 18 January 2018, www.theglobeandmail.com/opinion/women-dont-have-to-agreebut-we-do-need-to-fight-fair/article37660611/ (accessed 3 March 2018).

Benjamin, Walter, The Origin of German Tragic Drama (1928), trans. John Osborne (London, Verso, 2003).

Bennington, Geoffrey, Half Not No End: Militantly Melancholic Essays in Memory of Jacques Derrida (Edinburgh, Edinburgh University Press, 2010).

Butler, Judith, The Psychic Life of Power: Theories in Subjection (Stanford, CA, Stanford University Press, 1997).

Caruth, Cathy, Unclaimed Experience: Trauma, Narrative, and History (Baltimore, MD, Johns Hopkins University Press, 1996).

(ed.), Trauma: Explorations in Memory (Baltimore, MD, Johns Hopkins University Press, 1995).

Ciccariello-Maher, George, Decolonizing Dialectics (Durham, N.C., Duke University Press, 2017).

Derrida, Jacques, The Work of Mourning, ed. Pascale-Anne Brault and Michael Naas (Chicago, University of Chicago Press, 2001).

Fanon, Frantz, Black Skin, White Masks (1952), trans. Richard Philcox (New York, Grove Press, 2008). 2004).

The Wretched of the Earth (1961), trans. Richard Philcox (New York, Grove Press,

Felman, Shoshana, and Dori Laub, Testimony: Crises of Witnessing in Literature, Psychoanalysis, and History (New York, Routledge, 1991).

Foucault, Michel, The History of Sexuality, Volume 1: An Introduction (1976), trans. Robert Hurley (New York, Vintage, 1990).

Franke, Katherine, "Making White Supremacy Respectable. Again," Los Angeles Review of Books, 21 November 2016, http://blog.lareviewofbooks.org/essays/making-whitesupremacy-respectable/ (accessed 13 June 2018).

Gaffney, Jennifer, "Another Origin of Totalitarianism," Journal of the British Society for Phenomenology, 47:1 (2016), pp. 1-17. 
Halberstam, Jack, "Hiding the Tears in My Eyes-Boys Don't Cry-A Legacy," Bully Bloggers, 7 December 2016, https://bullybloggers.wordpress.com/2016/12/07/hiding-the-tears-inmy-eyes-boys-dont-cry-a-legacy-by-jack-halberstam/ (accessed 3 March 2018).

JanMohamed, Abdul R., The Death-Bound-Subject: Richard Wright's Archaeology of Death (Durham, N.C., Duke University Press, 2005).

Kafka, Franz, "A Country Doctor," in The Complete Stories, ed. Nahum N. Glatzer (New York, Schocken, 1983), pp. 220-5.

Lilla, Mark, "The End of Identity Liberalism," New York Times, 18 November 2016, www. nytimes.com/2016/11/20/opinion/sunday/the-end-of-identity-liberalism.html?_r=0 (accessed 13 June 2018).

The Once and Future Liberal: After Identity Politics (New York, Harper, 2017).

McIvor, David W., “The Struggle for Integration: James Baldwin and Melanie Klein in the Context of Black Lives Matter," James Baldwin Review, 2 (2016), pp. 75-96.

Nyongo, Tav, "Civility Disobedience," Bully Bloggers, 18 August 2014, https://bullybloggers. wordpress.com/2014/08/18/civility-disobedience/ (accessed 11 January 2017).

Ocbazghi, Emmanuel, "President Responds to a Shooting at Congressional Baseball Practice at Virginia," Business Insider, 14 July 2017, www.businessinsider.com/president-trumpresponds-shooting-congressional-baseball-practice-virginia-police-gun-steve-scalise2017-6 (accessed 15 June 2017).

Oliver, Kelly, "If This Is Feminism...," Philosophical Salon, 8 May 2017, http://the philosophi-calsalon.com/if-this-is-feminism-its-been-hijacked-by-the-thought-police/ (accessed 3 March 2018).

Patterson, Orlando, Slavery and Social Death: A Comparative Study (Cambridge, MA, Harvard University Press, 1982).

Phillips, Adam, Becoming Freud: The Making of a Psychoanalyst (New Haven, CT, Yale University Press, 2014).

Said, Edward W., Freud and the Non-European (London, Verso, 2004).

Schulman, Sarah, Conflict Is Not Abuse: Overstating Harm, Community Responsibility, and the Duty of Repair (Vancouver, Arsenal Pulp Press, 2016).

Sedgwick, Eve Kosofsky, "Paranoid Reading and Reparative Reading; or, You're So Paranoid, You Probably Think This Introduction Is about You," in Eve Kosofsky Sedgwick (ed.), Novel Gazing: Queer Readings in Fiction (Durham, N.C., Duke University Press, 1997), pp. 1-37.

Thorsen, Karen (dir.), James Baldwin: The Price of the Ticket, Maysles Films and PBS/American Masters, 1989.

Wright, Richard, "Blueprint for Negro Writing" (1937), in Richard Wright Reader, ed. Ellen Wright and Michel Fabre (New York, Da Capo Press, 1997), pp. 36-49. Native Son (1940) (New York, Perennial, 1993).

\section{Contributor's Biography}

Mikko Tuhkanen is Associate Professor of English at Texas A\&M University. He is the author, among other works, of The Essentialist Villain: On Leo Bersani (2018) and the co-editor, with E. L. McCallum, of The Cambridge History of Gay and Lesbian Literature (2014). His essay "Watching Time: James Baldwin and Malcolm X" appeared in James Baldwin Review 2 (2016). 